\title{
The Malaysia DREEM: perceptions of medical students about the learning environment in a medical school in Malaysia
}

This article was published in the following Dove Press journal:

Advances in Medical Education and Practice

9 June 2014

Number of times this article has been viewed

\begin{abstract}
Redhwan A Al-Naggar'
Mahfoudh Abdulghani ${ }^{2,14}$

Muhamed T Osman ${ }^{3}$

Waqar Al-Kubaisy'

Aqil Mohammad Daher ${ }^{15}$

Khairun Nain Bin Nor Aripin ${ }^{4}$

Ali Assabri ${ }^{5}$

Dawood A Al-Hidabi ${ }^{6}$

Mohamed Izham B Mohamed Ibrahim ${ }^{7}$

Ahmed Al-Rofaai ${ }^{8}$

Hisham S Ibrahim 9

Hassanain Al-Talib ${ }^{10}$

Alyaa Al-Khateeb"

Gamil Qasem Othman ${ }^{6}$

Qaid Ali Abdulaziz ${ }^{6}$

Karuthan Chinna ${ }^{12}$

Yuri V Bobryshev ${ }^{13}$

'Population Health and Preventive Medicine Department, Faculty of Medicine, Universiti Teknologi MARA, ${ }^{2}$ Pharmacology Department, International Medical School, Management and Science University, 3Department of Pathology, Faculty of Medicine \& Defence Health, National Defence University of Defence Health, National Defence University of
Malaysia, Kuala Lumpur, Malaysia, ${ }^{4}$ Faculty of Medicine and Health Sciences, Islamic Science University of Malaysia, Kuala Lumpur, Malaysia; ${ }^{5} \mathrm{Community}$ Medicine Department, Faculty of Medicine and Health Science, Sana'a University, 'University of Science and Technology, Sana' a, Yemen : ${ }^{7} \mathrm{College}$ of Pharmacy, Qatar Univerty University, Doha, Qatar,' School of Biological Sciences, Universiti Sains Malaysia, Minden, Penang, Malaysia, ${ }^{9}$ Physiology Discipline-Faculty Of Medicine and Healt Sciences-Universiti Sultan Zainal Abidin, Terengganu, Malaysia, ${ }^{10}$ Laboratory Medical Science Cluster, Drug Discovery \& Health Community of Research, Faculty of Medicine, Universiti Teknologi MARA, "Biochemistry and Molecular Medicine Discipline, Drug Discovery \& Health Community of Research, Faculty of Medicine, Universiti Teknologi MARA, ${ }^{2}$ Social and Preventive Medicine, University Malaya, Kuala Lumpur, Malaysia; Medicine, University Malaya, Kuala Lumpur, Malaysia;
${ }^{13}$ Faculty of Medicine, School of Medical Sciences, University of New South Wales, Sydney, NSW, Australia; ${ }^{14}$ Pharmacology Department, Unaizah College of Pharmacy (UCP), Qassim University, Al Qassim, Saudi Arabia; ${ }^{15}$ Department of Community medicine, Faculty of Medicine \& Defence Health, National Defence University of Malaysia, Kuala Lumpur, Malaysia
\end{abstract}

Correspondence: Yuri V Bobryshev Faculty of Medicine, School of Medical Sciences, University of New South Wales, New South

Wales, Sydney, NSW 2052, Australia

Wales, Sydney, NSW

Tel $+6129385 \quad 1217$
Fax $+6129385 \quad 1217$

Email y.bobryshev@unsw.edu.au
Background: Students' perceptions of their learning environment, by defining its strengths and weaknesses, are important for continuous improvement of the educational environments and curriculum. Therefore, the aim of this study was to explore students' perceptions of their learning environment, among medical students in Malaysia. Various aspects of the education environment were compared between year levels and sex.

Methods: This cross-sectional study was conducted at the Management and Science University, Shah Alam, Malaysia in 2012. A total number of 438 medical students participated in this study, and the response rate was $87.6 \%$. Data were analyzed using SPSS. Comparisons of the mean scores of Dundee Ready Education Environment Measure (DREEM) subscales were calculated. The $t$-test was used to determine statistically significant differences.

Results: The majority of the study participants were female, Malay, and from year $3(68.7 \%$, $65.3 \%$, and $55.7 \%$; respectively). Analysis of each of the 50 items of the DREEM inventory showed that 47 items scored ranged between 2.00 and 3.00, and three items scored below 2.00. These were identified as problem areas in this medical school that are required to be critically addressed. The overall score showed that the medical students' perceptions were positive. The students' perception toward educational environment was positive for all five DREEM subscales.

Conclusion: The study found that, in general, the perceptions of the participants about the learning environment were positive. Nevertheless, the study also found there is a need for curriculum improvement in this school and identified priority areas for such improvement.

Keywords: students' perceptions, DREEM, Malaysia, learning environment, medical education

\section{Introduction}

The medical educational environment is increasingly becoming the focus of research globally. ${ }^{1,2}$ It is commonly understood that educational environments are an important factor for efficient learning. ${ }^{3,4}$ Therefore, assessment of the educational environments has been identified as a key instrument for the delivery of high quality education. . $^{3,4}$ This has been reported in a number of studies that examined educational environment among factors that are thought to be important for the success of an effective curriculum. $^{5-7}$

A number of previous studies showed that educational environments positively correlate with academic success and satisfaction with educational curriculum. ${ }^{8,9}$ Excellent learning has been found to positively correlate with the educators' perceptions of the educational environments. It influences how, why, and what students learn..$^{9,10}$ 
Measurements of the education environments in primary and secondary education have been commonly accepted for decades. ${ }^{11-14} \mathrm{~A}$ number of instruments for measuring the medical education environments have also been developed. ${ }^{15-20} \mathrm{~A}$ study by Roff et $\mathrm{al}^{21}$ described the development and validation of the Dundee Ready Education Environment Measure (DREEM). This instrument is a general, multidimensional, multicultural instrument. It gives a universal score of a maximum of 200 and is capable of measuring five separate elements of the education environment: Students' Perceptions of Learning (SPoL), Students' Perceptions of Teachers (SPoT), Students' Perceptions of Atmosphere (SPoA), Students' Academic Self-Perception (SASP), and Student's Social Self-Perceptions (SSSP). ${ }^{21}$ The DREEM instrument can be used to highlight the weaknesses and strengths of any educational institution, compare the performance and success of medical schools, and make comparisons among students in different levels of study and of different sex. ${ }^{9,22}$ In addition, this tool can be used to help amend the curriculum, in comparing present and past programs, and for the examination and evaluation of the effectiveness of a university curriculum. ${ }^{6-23}$ The DREEM can also be useful in helping health and medical schools to distinguish their priorities. ${ }^{22-26}$ In addition, it enables institutions to compare their performances and productivities with their peers, which can be educationally insightful. ${ }^{24}$ It is established nowadays that the value of DREEM is in providing a consistent method for global comparisons between medical schools and also, in allowing them to standardize their educational environments. ${ }^{25}$ The DREEM has been successfully used in research carried out in North America, Africa, Europe, South America, the Middle East and Asia. ${ }^{26}$ Previous study has been able to achieve a number of goals, including the generation of a profile of institutional/course strengths and weaknesses, and the testing and application of intra- and interinstitutional benchmarking to predict student performance. ${ }^{26}$ It is well understood nowadays that monitoring the perceptions of students is necessary in order to continuously improve the educational environment, by defining its strengths and weaknesses. ${ }^{26}$

Despite the obvious potential value of the application of DREEM for analysis of medical education problems, this tool is not commonly used in Malaysia. Therefore, the aim of our study was to explore students' perceptions of their learning environment, among medical students in one of the medical schools in Malaysia. In this study, various aspects of the education environment were compared between year levels and sex.

\section{Methods \\ Participants}

This cross-sectional study was conducted at the Management and Science University, Malaysia, in 2012. The target population included medical students in years 1, 2, and 3 at the International Medical School, Management and Science University. The International Medical School had 610 medical students at that time, but not all of them were present at the time when the study was carried out. Thus, in our study, questionnaires were distributed randomly among 500 medical students. Sixty-two students were excluded from the study analysis as these students either failed to return the questionnaire or did not complete it. Therefore, in total, 438 questionnaires were analyzed (response rate $=87.6 \%$ ).

The protocol of this study was approved by the Ethics Committee of Management and Science University, Malaysia. Following precise instructions and explanation of the aim of the study, the questionnaires were distributed randomly to the students.

\section{Measures}

The perceptions of medical students in this study were assessed using the DREEM criteria. In our study, the DREEM instrument was used. ${ }^{21}$ The DREEM measured the five previously described subscales: the SASP, SPoT, SPoL, SSSP, and the SPoA. This instrument contained 50 items about topics directly related to educational environments. ${ }^{21}$ The students were asked to read all the statements and to answer using a five-point Likert scale ranging from "strongly agree" to "strongly disagree". The scoring of items was as follows: $4=$ strongly agree, $3=$ agree, $2=$ uncertain, $1=$ disagree, and $0=$ strongly disagree. Nine items $(4,8,9$, $17,25,35,39,48$, and 50) were scored in reverse. A higher score indicated a more positive evaluation - in the original version, the DREEM (50 items) has a maximum score of 200 , demonstrating the perfect educational environment. ${ }^{21}$ Items with mean score of 3.5 or over were classed as "real positive points".

The DREEM was developed by the international Delphi panel, involving more than eighty health and medical profession educators from all continents all over the world. ${ }^{24,26,27}$ The fifty items in the scale were considered to be the constituents of a good learning environment for undergraduates in the health professions. ${ }^{6,24,26,27}$ The development and validation of the DREEM has been reported. ${ }^{27}$

The previous Malaysian study using the DREEM reported an "acceptable level of constancy and a high level of internal consistency of the instrument (DREEM) to be used in the 
local environment to measure educational environments in Malaysia". ${ }^{28}$

\section{Data analysis}

Data were analyzed using SPSS version 18 (IBM Corp, Armonk, NY, USA). Comparisons of the mean scores of males and females were included. The Student's $t$-test was used to determine statistically significant differences. Oneway analysis of variance (ANOVA) was carried out to analyze the difference between the mean scores of the three different years. For this study, $P<0.05$ was considered statistically significant.

\section{Results}

A total number of 438 medical students from the Management and Science University participated in this study. The majority were females, Malay, and from year $3(68.7 \%, 65.3 \%$, and $55.7 \%$; respectively) (Table 1).

\section{Students' Perceptions of Learning}

In the SPoL subscale, the 12 items scored between 2.00 and 3.00. These indicated the aspects of the domain that could be improved (Table 2).

\section{Students' Perceptions of Teachers}

The SPoT subscale included eleven items. Item 39, which asked whether "The teachers get angry in teaching", and item 50 , which asked whether "The students irritate the teachers", both negative items, scored 1.99 (standard deviation [SD] 0.98) and 1.91 (SD 0.95), respectively, indicating the students' agreement with the items. This could mean that these items indicate problem areas and should be investigated closely. The other items scored between 2.00 and 3.00, indicating the aspects of this domain that could be improved (Table 3).

Table I Sociodemographic characteristics of the medical students from the Management and Science University, who participated in this study $(n=438)$

\begin{tabular}{llll}
\hline Variable & Categorize & Number & Percentage (\%) \\
\hline Sex & Male & 137 & 31.3 \\
& Female & 301 & 68.7 \\
Race & Malay & 286 & 65.3 \\
& Chinese & 35 & 8.0 \\
& Indian & 103 & 23.5 \\
& Others & 14 & 3.2 \\
Year & Year I & 34 & 7.8 \\
& Year 2 & 160 & 36.5 \\
& Year 3 & 244 & 55.7 \\
\hline
\end{tabular}

Table 2 Students' perceptions of learning, among medical students $(n=438)$

\begin{tabular}{lll}
\hline Items & Mean & SD \\
\hline I. I am encouraged to participate in class & 2.6 & 0.83 \\
7. The teaching is often stimulating & 2.6 & 0.77 \\
I3. The teaching is student centered & 2.5 & 0.80 \\
I6. The teaching helps to develop my competence & 2.6 & 0.82 \\
20. The teaching is well focused & 2.6 & 0.79 \\
22. The teaching helps to develop my confidence & 2.6 & 0.79 \\
24. The teaching time is put to good use & 2.5 & 0.84 \\
25. The teaching over-emphasizes factual learning & 2.4 & 0.83 \\
38. I am clear about the learning objectives of the & 2.6 & 0.76 \\
course & & \\
44. The teaching encourages me to be an active & 2.6 & 0.8 I \\
learner & & \\
47. Long term learning is emphasized over short & 2.4 & 0.8 I \\
term learning & & \\
48. The teaching is too teacher-centered & 2.1 & 0.86 \\
Total mean score & 30.6 & 5.48 \\
Maximum score & 48 & \\
\hline
\end{tabular}

Abbreviation: SD, standard deviation.

\section{Students' Academic Self-Perception}

In the analysis of individual items of the SASP subscale, which included eight items, the item scores ranged between 2.00 and 3.00, indicating areas that need to be improved (Table 4).

\section{Students' Perceptions of Atmosphere}

The SPoA subscale included 12 items. The highest mean scores recorded were for the items "There are opportunities for me to develop interpersonal skills" and "I feel comfortable in the class socially". The lowest score was for the statement "I find the experience is disappointing" (Table 5).

Table 3 Students' perceptions of teachers, among medical students $(n=438)$

\begin{tabular}{lll}
\hline Items & Mean & SD \\
\hline 2. The teachers are knowledgeable & 2.9 & 0.77 \\
6. The teachers are patient with students & 2.7 & 0.77 \\
8. The teachers ridicule the students & 2.1 & 0.89 \\
9. The teachers are authoritarian & 2.3 & 0.86 \\
18. The teachers have good communication skills & 2.7 & 0.83 \\
$\quad$ with students & & \\
29. The teachers are good at providing feedback & 2.7 & 0.76 \\
to students & & \\
32. The teachers provide constructive criticism here & 2.5 & 0.75 \\
37. The teachers give clear examples & 2.7 & 0.77 \\
39. The teachers get angry in class & 1.9 & 0.98 \\
40. The teachers are well prepared for their classes & 2.7 & 0.84 \\
50. The students irritate the teachers & 1.9 & 0.95 \\
Total mean score & 27.4 & 4.44 \\
Maximum score & 44 & \\
\hline
\end{tabular}

Abbreviation: SD, standard deviation. 
Table 4 Students' academic self-perception, among medical students $(n=438)$

\begin{tabular}{lll}
\hline Items & Mean & SD \\
\hline $\begin{array}{l}\text { 5. Learning strategies which worked for me } \\
\quad \text { before continue to work for me now }\end{array}$ & 2.5 & 0.84 \\
$\begin{array}{l}\text { 10. I am confident about my passing this year } \\
\text { 21. I feel I am being well prepared for my profession }\end{array}$ & 2.6 & 0.78 \\
$\begin{array}{l}\text { 26. Last year's work has been a good preparation } \\
\quad \text { for this year's work }\end{array}$ & 2.4 & 0.79 \\
27. I am able to memorize all I need & 2.3 & 0.84 \\
31. I have learned a lot about empathy in my & 2.7 & 0.89 \\
$\quad$ profession & & \\
4I. My problem solving skills are being well & 2.6 & 0.79 \\
$\quad$ developed here & & \\
45. Much of what I have to learn seems relevant & 2.7 & 0.75 \\
$\quad$ to a career in healthcare & & \\
$\begin{array}{l}\text { Total mean score } \\
\text { Maximum score }\end{array}$ & 20.65 & 3.86 \\
\hline
\end{tabular}

Abbreviation: SD, standard deviation.

\section{Students' Social Self-Perception}

The SSSP subscale included seven items. One item indicating a problem area was item 4 ("I am too tired to enjoy the course"), which had a mean score of 1.90 . The other items scored between 2.00 and 3.00, indicating a need for further enhancement (Table 6).

A total of 47 items scored between 2.00 and 3.00; this suggests that these areas could be enhanced to improve the educational environments in this university. A total of three items scored below 2.00. These could be thought to identify "real" problems in our school educational environment and thus, we believe, need urgent investigation.

Table 5 Students' perceptions of atmosphere, among medical students $(n=438)$

\begin{tabular}{lll}
\hline Items & Mean & SD \\
\hline II. The environments are relaxing during the ward & 2.4 & 0.75 \\
teaching & 2.1 & 1.07 \\
I2. This school is well timetabled & 2.3 & 0.97 \\
I7. Cheating is a problem in this school & 2.5 & 0.77 \\
23. The atmosphere is relaxing during lectures & 2.7 & 0.80 \\
30. There are opportunities for me to develop & & \\
interpersonal skills & 2.7 & 1.22 \\
33. I feel comfortable in class socially & 2.5 & 0.79 \\
34. The atmosphere is relaxing during seminars/ & & \\
tutorials & 2.0 & 0.96 \\
35. I find the experience disappointing & 2.5 & 0.78 \\
36. I am able to concentrate well & 2.5 & 0.85 \\
42. The enjoyment outweighs the stress of the course & 2.6 & 0.79 \\
43. The atmosphere motivates me as a learner & 2.6 & 0.80 \\
49. I feel able to ask the questions I want & 29.7 & 5.27 \\
Total mean score & 48 & \\
Maximum score & & \\
\hline Abbreviation: SD, standard devation & &
\end{tabular}

Abbreviation: SD, standard deviation.
Table 6 Students' social self-perceptions, among medical students $(n=438)$

\begin{tabular}{lll}
\hline Items & Mean & SD \\
\hline 3. There is a good support system for students & 2.2 & 0.89 \\
who get stressed & & \\
4. I am too tired to enjoy the course & 1.9 & 1.04 \\
14. I am rarely bored on this course & 2.0 & 1.09 \\
I5. I have good friends in this school & 2.9 & 0.79 \\
19. My social life is good & 2.7 & 0.82 \\
28. I seldom feel lonely & 2.3 & 0.94 \\
46. My accommodation is pleasant & 2.4 & 0.91 \\
Total mean score & 16.7 & 3.35 \\
Maximum score & 28 & \\
\hline
\end{tabular}

Abbreviation: SD, standard deviation.

Table 7 shows the DREEM overall and subscale mean scores among the medical students. The overall score was 125.3/200 (SD 19.5). The overall score indicates that the medical students' perceptions of the educational environment of the school were more positive than negative. The total mean score for the SPoL was 30.6/48 (SD 5.4), SPoT was 27.4/44 (SD 4.4), SASP was 20.6/32 (SD 3.8), SPoA was 29.7/48 (SD 5.2), and for the SSSP was 16.7/28 (SD 3.3). The students' perceptions toward the educational environment were positive for all five DREEM subscales.

\section{DREEM scores by year of enrollment and sex}

Significant differences were found between the year levels of enrollment for total DREEM score and the SPoT, SPoL, SASP, SPoA, and SSSP subscale scores $(<0.001,<0.001,<0.001$, $<0.001,<0.001$, and 0.043 ; respectively) (Tables 8 and 9 ).

Table 10 shows that there were significant differences in the perceptions of the male and female students in six items,

Table 7 DREEM domains for medical students $(n=438)$

\begin{tabular}{lllll}
\hline Domain & $\begin{array}{l}\text { Number of } \\
\text { questions }\end{array}$ & $\begin{array}{l}\text { Maximum } \\
\text { DREEM } \\
\text { score }\end{array}$ & Mean & SD \\
\hline $\begin{array}{l}\text { Students' Perceptions } \\
\text { of Learning (SPoL) }\end{array}$ & 12 & 48 & 30.6 & 5.4 \\
$\begin{array}{l}\text { Students' Perceptions } \\
\text { of Teachers (SPoT) }\end{array}$ & 11 & 44 & 27.4 & 4.4 \\
$\begin{array}{l}\text { Students' Academic } \\
\text { Self-Perception (SASP) }\end{array}$ & 8 & 32 & 20.6 & 3.8 \\
$\begin{array}{l}\text { Students' Perceptions } \\
\text { of Atmosphere (SPoA) }\end{array}$ & 12 & 48 & 29.7 & 5.2 \\
$\begin{array}{l}\text { Students' Social Self- } \\
\text { Perceptions (SSSP) }\end{array}$ & 7 & 28 & 16.7 & 3.3 \\
\begin{tabular}{l} 
Total DREEM score \\
\hline
\end{tabular} & 50 & 200 & 125.3 & 19.5 \\
\hline
\end{tabular}

Abbreviations: DREEM, Dundee Ready Education Environment Measure; SD, standard deviation. 
Table 8 ANOVA between different years for the differing DREEM domains $(n=438)$

\begin{tabular}{llll}
\hline Domain & Year levels & Mean \pm SD & P-value \\
\hline Students' Perceptions & Year I & $31.2 \pm 5.9$ & \\
of Learning & Year 2 & $32.2 \pm 4.3$ & $<0.00$ I \\
& Year 3 & $29.5 \pm 5.8$ & \\
Students' Perceptions & Year I & $27.9 \pm 5.3$ & \\
of Teachers & Year 2 & $28.6 \pm 3.5$ & $<0.00$ I \\
Students' Academic & Year 3 & $26.6 \pm 4.6$ & \\
Self-Perception & Year I & $21.2 \pm 3.1$ & \\
& Year 2 & $21.6 \pm 3.4$ & $<0.00$ I \\
Students' Perceptions & Year 3 & $19.9 \pm 4.0$ & \\
of Atmospheres & Year I & $30.9 \pm 4.4$ & \\
& Year 3 & $30.9 \pm 4.8$ & $<0.00$ I \\
Students' Social Self- & Year I & $28.8 \pm 5.4$ & \\
Perceptions & Year 2 & $17.3 \pm 3.0$ & \\
& Year 3 & $17.0 \pm 3.2$ & 0.043 \\
Total scores & Year I & $16.3 \pm 3.4$ & \\
& Year 2 & $128 \pm 19.0$ & \\
& Year 3 & $130 \pm 16.6$ & $<0.00$ I I \pm 20.4 \\
\hline
\end{tabular}

Abbreviations: ANOVA, analysis of variance; DREEM, Dundee Ready Education Environment Measure; SD, standard deviation. with higher female satisfaction with the education environment. Notably, males scored more negatively on several aspects of the educational environment than did the females.

\section{Discussion}

Educational environments are an important factor to determine the effectiveness and success of a medical school curriculum. ${ }^{5}$ Therefore, our study aimed to evaluate the education environment as perceived by medical students at the International Medical School of the Management and Science University, Malaysia. It also aimed to determine the different perceptions among students from different yearlevels and between the sexes.

According to McAleer and Roff, ${ }^{29}$ a mean score between 50 and 100 indicates serious problems. The overall DREEM mean score in our study was $125.3 / 200$, which fell well inside the range (101-150) being indicative of a "more positive than negative" perception of the environment. ${ }^{30,31}$ Higher overall mean scores were reported in two earlier Malaysian studies, in

Table 9 Statistically significant differences between years $(n=438)$

\begin{tabular}{|c|c|c|c|c|}
\hline Statements & Year I & Year 2 & Year 3 & $P$-value \\
\hline I am encouraged to participate & $2.74 \pm 0.75$ & $2.82 \pm 0.61$ & $2.57 \pm 0.96$ & 0.013 \\
\hline The teachers are knowledgeable & $3.06 \pm 0.73$ & $3.18 \pm 0.63$ & $2.86 \pm 0.83$ & $<0.001$ \\
\hline The teachers are patient with the students & $2.56 \pm 0.89$ & $2.83 \pm 0.63$ & $2.65 \pm 0.83$ & 0.036 \\
\hline The teaching is often stimulating & $2.53 \pm 0.96$ & $2.78 \pm 0.72$ & $2.59 \pm 0.80$ & 0.044 \\
\hline The teachers are authoritarian & $2.26 \pm 0.89$ & $2.48 \pm 0.81$ & $2.24 \pm 0.87$ & 0.021 \\
\hline I am confident about my passing this year & $2.94 \pm 0.8 \mathrm{I}$ & $2.89 \pm 0.60$ & $2.53 \pm 0.84$ & $<0.001$ \\
\hline The environments are relaxing during the ward teaching & $2.62 \pm 0.55$ & $2.53 \pm 0.73$ & $2.36 \pm 0.78$ & 0.042 \\
\hline I have good friends in this school & $3.00 \pm 0.49$ & $3.19 \pm 0.63$ & $2.73 \pm 0.86$ & $<0.001$ \\
\hline The teaching is sufficiently concerned to develop my competence & $2.68 \pm 0.97$ & $2.75 \pm 0.73$ & $2.49 \pm 0.83$ & 0.006 \\
\hline The teachers have good communication & $2.7 I \pm 0.76$ & $2.9 I \pm 0.72$ & $2.67 \pm 0.89$ & 0.017 \\
\hline The teaching is well focused & $2.56 \pm 0.99$ & $2.79 \pm 0.63$ & $2.58 \pm 0.83$ & 0.020 \\
\hline I feel I am being well prepared for my profession & $2.76 \pm 0.8 \mathrm{I}$ & $2.65 \pm 0.64$ & $2.48 \pm 0.86$ & 0.037 \\
\hline The teaching is sufficiently concerned to develop my confidence & $2.68 \pm 0.99$ & $2.74 \pm 0.65$ & $2.51 \pm 0.83$ & 0.018 \\
\hline The environments are relaxing during lectures & $2.62 \pm 0.73$ & $2.7 I \pm 0.68$ & $2.46 \pm 0.82$ & 0.008 \\
\hline The teaching time is put to good use & $2.82 \pm 0.62$ & $2.68 \pm 0.71$ & $2.42 \pm 0.92$ & 0.001 \\
\hline The teaching over-emphasized factual learning & $2.83 \pm 0.81$ & $2.63 \pm 0.64$ & $2.31 \pm 0.92$ & 0.001 \\
\hline Last year's work has been a good preparation for this year's work & $2.15 \pm 0.74$ & $2.63 \pm 0.82$ & $2.39 \pm 0.85$ & 0.001 \\
\hline The teachers are good at providing feedback to students & $2.68 \pm 0.76$ & $2.89 \pm 0.59$ & $2.61 \pm 0.84$ & 0.002 \\
\hline The teachers provide constructive criticism here & $2.62 \pm 0.69$ & $2.66 \pm 0.69$ & $2.45 \pm 0.78$ & 0.018 \\
\hline I feel comfortable in class socially & $2.82 \pm 0.62$ & $2.79 \pm 0.70$ & $2.58 \pm 0.88$ & 0.017 \\
\hline The atmosphere is relaxing during seminars/tutorials & $2.68 \pm 0.72$ & $2.76 \pm 0.61$ & $2.47 \pm 0.89$ & 0.002 \\
\hline The teachers give clear examples & $2.62 \pm 0.88$ & $2.86 \pm 0.67$ & $2.63 \pm 0.80$ & 0.011 \\
\hline I am clear about the learning objectives of the course & $2.44 \pm 0.61$ & $2.8 I \pm 0.66$ & $2.59 \pm 0.83$ & 0.004 \\
\hline The teachers get angry in class & $2.4 I \pm 0.74$ & $1.87 \pm 0.99$ & $2.02 \pm 0.97$ & 0.012 \\
\hline The teachers are well prepared for their classes & $2.7 I \pm 0.93$ & $2.99 \pm 0.64$ & $2.59 \pm 0.90$ & $<0.001$ \\
\hline My problem solving skills are being well developed here & $2.62 \pm 0.69$ & $2.77 \pm 0.66$ & $2.52 \pm 0.87$ & 0.011 \\
\hline The teaching encourages me to be an active learner & $2.82 \pm 0.62$ & $2.88 \pm 0.63$ & $2.48 \pm 0.89$ & $<0.001$ \\
\hline Much of what I have to learn seems relevant to a career in medicine & $2.74 \pm 0.75$ & $2.96 \pm 0.56$ & $2.57 \pm 0.82$ & $<0.001$ \\
\hline Long term learning is emphasized over short term learning & $2.59 \pm 0.65$ & $2.61 \pm 0.66$ & $2.39 \pm 0.90$ & 0.027 \\
\hline I feel able to ask the questions I want & $2.50 \pm 0.6 \mathrm{I}$ & $2.82 \pm 0.69$ & $2.53 \pm 0.87$ & 0.001 \\
\hline
\end{tabular}


Table 10 Statistically significant differences between male and female medical students $(n=438)$

\begin{tabular}{|c|c|c|c|c|}
\hline Item & Statements & Male & Female & $P$-value \\
\hline \multirow[t]{6}{*}{2} & $\begin{array}{l}\text { The teachers are } \\
\text { knowledgeable }\end{array}$ & $2.85 \pm 0.79$ & $3.05 \pm 0.75$ & 0.014 \\
\hline & $\begin{array}{l}\text { The teaching helps to } \\
\text { develop my confidence }\end{array}$ & $2.48 \pm 0.89$ & $2.65 \pm 0.78$ & 0.036 \\
\hline & $\begin{array}{l}\text { I am clear about the } \\
\text { objective of the course }\end{array}$ & $2.53 \pm 0.90$ & $2.72 \pm 0.69$ & 0.023 \\
\hline & $\begin{array}{l}\text { The teaching encourages } \\
\text { me to be an active learner }\end{array}$ & $2.53 \pm 0.86$ & $2.7 I \pm 0.77$ & 0.037 \\
\hline & $\begin{array}{l}\text { Much of what I have to } \\
\text { learn seems relevant to a } \\
\text { career in medicine }\end{array}$ & $2.60 \pm 0.79$ & $2.78 \pm 0.72$ & 0.024 \\
\hline & $\begin{array}{l}\text { The students irritate the } \\
\text { teachers }\end{array}$ & $2.05 \pm 0.99$ & $1.85 \pm 0.92$ & 0.038 \\
\hline
\end{tabular}

which the overall mean scores were $133 / 200$ and 134/200..$^{32,33}$ Lower overall scores (119/200, 114/200, and 107/200) were reported in repeated studies from India. ${ }^{5,9}$ Lower overall scores also were reported in Sri Lanka, Nigeria, and Trinidad, with overall scores of $108 / 200,{ }^{30} 118 / 200,{ }^{10}$ and $109 / 200,{ }^{6}$ respectively. The lowest score, 89/200, was reported in Saudi Arabia at the College of Medicine at King Saud University, ${ }^{34}$ followed by a score of $97 / 200$ reported by a study of the Canadian Memorial Chiropractic College. ${ }^{35}$ Higher overall scores were reported in Nepal and in the United Kingdom, with overall scores of $130 / 200{ }^{10}$ and $139 / 200,{ }^{36}$ respectively. An overall mean DREEM score of $125 / 200$, similar to that obtained in our study, was reported in another Malaysian study. ${ }^{37}$ A few previous studies showed higher total scores than in our study, ${ }^{2,36-38}$ which may indicate that these institutions are somewhat innovative in providing a student-centered approach to education. ${ }^{2}$

All students perceived "a more positive approach" (30.6/48) for their learning; "moving in the right direction" (27.4/44) for their teachers; "feeling more on the positive side" (20.6/32) for their academic self-perception; "a more positive environment" (29.7/48) for the atmosphere; and "not too bad" (16.7/28) for their social self-perception. These results should encourage and motivate the curriculum planners in our institute to raise students' perceptions about their educational environments to the highest level. In our study, the scores for all five subscales showed positive perceptions of the study participants. Nevertheless, there is a need for improvement in all five domains of the educational environments at the Management and Science University. This conclusion is in accordance with similar findings that were reported by Lai et al, ${ }^{33}$ from a study performed in Saudi Arabia. ${ }^{23,24}$
There were three DREEM items that scored 2 or less. The low scores suggest these items should be examined more closely as they indicate problem areas. Two items belonged to the SPoT subscale ("The teachers get angry in class"; "The students irritate the teachers") and another belonged to the SSSP subscale ("I am too tired to enjoy the course"). The item "I find the experience disappointing" (2.0) belonged to the SPoA subclass. These findings are indicative of the fact that these areas should be examined more closely as they relate to problem areas.

In our study, the students reported that the teaching was too teacher-centered. This finding is consistent with the findings of Mayya and Roff. ${ }^{9}$ In that study, students' perceptions about enjoying the course were found to be average, with a mean scoring of 2 . In our study, the students identified two items with means of more than 2.8 , and these can be regarded as strengths ("The teachers are knowledgeable" [2.9]; "I have good friends in this school" [2.9]). In a previous study ${ }^{39}$ low scores were found to be related to a good support system for students who get stressed during their study. Similarly, in a previous study, "memorize all information needed" showed low scores, similar to the findings in the present study. In a study conducted in Saudi Arabia, ${ }^{23,24}$ the item "There is a good support system for students who get stressed" had a very poor score, of 0.9. A low rating of this item indicated a lack of support available for stressed students.

In our study, there were 30 items that were scored between 2.50 and 3.00. These items are aspects of the educational environment that could be enhanced. ${ }^{29}$ They were items 1 (2.6), 7 (2.6), 13(2.5), 16 (2.6), 20 (2.6), 22 (2.6), 24 (2.5), and 38 (2.6) of the SPoL domain. This corresponded to student perceptions that their teachers encouraged them to participate in class, that the teachers stimulated them to participate in the teaching sessions, that the teaching was student-centered, that the teaching developed their competence and confidence, that the teaching was well focused, and that students felt clear about the learning objectives of the course. The scores of items 2 (2.9), 6 (2.7), 18 (2.7), 29 (2.7), 32 (2.5), 37 (2.7), and 40 (2.5) of the SPoT domain suggested that the students felt that their teachers were knowledgeable, well prepared for their classes, that teachers were good at communicating with them, and that teachers were good at providing feedback and criticism to students. Items 5 (2.5), 10 (2.6), 21 (2.5), 31 (2.7), and 45 (2.7) of the SASP domain corresponded to the following: "Learning strategies which worked for me before continue to work for me now"; "I am confident about my passing this year"; "I feel I am being well prepared for my profession"; "I have learned a lot about empathy in my 
profession"; and "Much of what I have to learn seems relevant to a career in medicine". Items 23 (2.5), 30 (2.7), 33 (2.7), 34 (2.5), 36 (2.5), 42 (2.5), 43 (2.6), and 49 (2.6) of the SPoA domain and items 15 (2.9) and 19 (2.7) of the SSSP domain included the following statements: "The environments are relaxing during lectures"; "There are opportunities for me to develop interpersonal skills"; "I feel comfortable in class socially"; "The environments are relaxing during seminars/ tutorials"; "I am able to concentrate well"; "The enjoyment outweighs the stress of studying medicine"; "The environments motivate me as a learner"; "I feel able to ask the questions I want"; "I have good friends in this school"; and "My social life is good". Some of the problem areas identified in the study population have also been identified as problems encountered in medical schools with traditional curricula. Two studies documented that students in traditional medical curricula perceived teaching as being too teacher-centered, overemphasizing factual learning with more authoritarian teachers. ${ }^{23,24}$ It was also observed that the students in these environments were more likely to feel tired, less able to memorize all they needed, and were less likely to enjoy the course. A possible explanation of the fact that the students were unable to memorize may be that there was an excessive volume of material to learn and no guidance given in prioritizing learning. Previous study showed that perceptions of students were linked with a risk of superficial learning, which in the long-term is associated with less retention of knowledge. ${ }^{40}$

In our study, students' perceptions about their learning environment showed the greatest difference between males and females. Mean scores were two points higher for females than males. A possible explanation for this finding may be that females perceived factors such as curriculum, structure, focus, and goals more positively than males. This is in agreement with a previous study that reported that males and females show different learning styles. ${ }^{41}$ This finding is also consistent with other earlier studies from the UK. ${ }^{21,31}$ However, it is essential to note here that this trend was opposite to the trend found in other studies that were carried out in the Middle East, ${ }^{1,2}$ the West Indies, ${ }^{6}$ and Sri Lanka. ${ }^{30}$

In our study there were significant differences in DREEM scores between males and females and year of study. A study by the Nepalese Health Sciences Institute showed significant sex and academic year differences. ${ }^{29} \mathrm{Al}-\mathrm{Sketty},{ }^{42}$ in his study at three institutes of nursing at the Sultanate of Oman, found variations in the DREEM score based on year of study and sex. Similar findings were reported by Al-Qahtani, ${ }^{43}$ namely, that sex showed statistically significant variations in the DREEM score. Sex-specific variations in the DREEM score in a study by Al-Hazimi et $\mathrm{al}^{23}$ identified that the female students were more satisfied than their male counterparts with the Dundee University Medical School (overall mean DREEM score 139/200).

\section{Conclusion}

A multicultural understanding of the environmental characteristics that influence learner growth and well-being is very important. The effectiveness of even the best pedagogy can be stymied by environmental factors that prevent learner engagement in the curriculum. Our study provides factual data about perceptions of the learning environment among medical students in Malaysia and provides some guidance on what needs to be addressed in the curriculum. Further continuous assessments of the learning environment are needed once changes are introduced, to evaluate whether these are effective.

\section{Acknowledgments}

The authors would like to thank the International Medical School, Management and Science University, Malaysia, for support.

\section{Disclosure}

The authors report no conflicts of interest in this work.

\section{References}

1. Roff S. Education, environment: a bibliography. Med Teach. 2005;27(4):353-357.

2. Roff S. The Dundee Ready Educational Environment Measure (DREEM) - a generic instrument for measuring students' perceptions of undergraduate health professions curricula. Med Teach. 2005;27(4): 322-325.

3. Newble D, Cannon R. A Handbook for Medical Teachers. 4th ed. Dordrecht: Kluwer Academic Publishers; 2001.

4. Dent J, Harden RM. A Practical Guide for Medical Teachers. 3rd ed. Amsterdam: Elsevier Health Sciences; 2009.

5. Abraham R, Ramnarayan K, Vinod P, Torke S. Students' perceptions of learning environment in an Indian medical school. BMC Med Educ. 2008;8:20.

6. Bassaw B, Roff S, McAleer S, et al. Students' perspectives on the educational environment, Faculty of Medical Sciences, Trinidad. Med Teach. 2003;25(5):522-526

7. Genn JM. AMEE Medical Education Guide No 23 (Part 1): Curriculum, environment, climate, quality and change in medical education - a unifying perspective. Med Teach. 2001;23(4):337-344.

8. Lizzio A, Wilson K, Simons R. University students' perceptions of the learning environment and academic outcomes: implications for theory and practice. Studies in Higher Education. 2002;27(1):27-52.

9. Mayya S, Roff S. Students' perceptions of educational environment: a comparison of academic achievers and under-achievers at Kasturba Medical College, India. Educ Health (Abingdon). 2004;17(3): 280-291. 
10. Roff S, McAleer S. What is educational climate? Med Teach. 2001;23: 333-334.

11. Pace CR, Stern GC. An approach to the measurement of the psychological characteristics of learning environment. J Educ Psychol. 1958;49: 269-277.

12. Fraser BJ. Development of short forms of several classroom environment scales. Journal of Educational Measurement. 1982;19(3):221-227.

13. Fraser BJ, Treagust DF. Validity and use of an instrument for assessing classroom psychosocial environment in higher education. Higher Education. 1986;15:37-57.

14. Moos RH, Trickett EJ. Classroom Environment Scale Manual. 2nd ed. Palo Alto, CA: Consulting Psychologists Press; 1987.

15. Hutchins EB. The 1960s medical school graduate: his perceptions of his faculty, peers, and environment. J Med Educ. 1961;36:322-329.

16. Rothman AI, Ayoade F. The development of learning environment: a questionnaire for use in curriculum evaluation. J Med Educ. 1970;45:754-759.

17. Levy M, Morse PK, Liebelt RA, Dallman JJ, McDonald TF. Use of the learning environment questionnaire to assess curricular change. J Med Educ. 1973;48(9):840-845.

18. Marshall RE. Measuring the medical school learning environment. J Med Educ. 1978;53(2):89-104.

19. Feletti GI, Clarke RM. Review of psychometric features of the Medical School Learning Environment Survey. Med Educ. 1981;15(2):92-96.

20. Wakeford RE. Students' perception of the medical school learning environment: a pilot study into some differences and similarities between clinical schools in the UK. Assessment and Evaluation in Higher Education. 1981;6(3):206-217.

21. Roff S, McAleer S, Harden RM, et al. Development and validation of the Dundee Ready Education Environment Measure (DREEM). Med Teach. 1997;19(4):295-299.

22. Roff S, McAleer S, Ifere OS, Bhattacharya S. A global diagnostic tool for measuring educational environment: comparing Nigeria and Nepal. Med Teach. 2001;23(4):378-382.

23. Al-Hazimi A, Al-Hyiani A, Roff S. Perceptions of the educational environment of the medical school in King Abdul Aziz University, Saudi Arabia. Med Teach. 2004;26(6):570-573.

24. Al-Hazimi A, Zaini R, Al-Hyiani A, et al. Educational environment in traditional and innovative medical schools: a study in four undergraduate medical schools. Educ Health (Abingdon). 2004;17(2):192-203.

25. Hammond SM, O’Rourke M, Kelly M, Bennett D, O’Flynn S. A psychometric appraisal of the DREEM. BMC Med Educ. 2012;12:2.

26. Denz-Penhey H, Murdoch JC. A comparison between findings from the DREEM questionnaire and that from qualitative interviews. Med Teach. 2009;31(10):e449-e453.

27. Pimparyon P, Caleer SM, Pemba S, Roff S. Educational environment, student approaches to learning and academic achievement in a Thai nursing school. Med Teach. 2000;22(4):359-364.

28. Yusoff MSB. Stability of DREEM in a sample of medical students: a prospective study. Education Research International. 2012;2012: 509638 .
29. McAleer S, Roff S. A practical guide to using the Dundee Ready Education Environment Measure (DREEM). In: Genn JM, editor. AMEE Medical Education Guide No 23 Curriculum, Environment, Climate, Quality and Change in Medical Education; A Unifying Perspective. Dundee: Association of Medical Education in Europe; 2001:29-33.

30. Jiffry MT, McAleer S, Fernando S, Marasinghe RB. Using the DREEM questionnaire to gather baseline information on an evolving medical school in Sri Lanka. Med Teach. 2005;27(4):348-352.

31. Dunne F, McAleer S, Roff S. Assessment of the undergraduate medical environment in a large UK medical school. Health Educ J. 2006;65(2):149-158.

32. Hassan II. A Study of Stressors and Coping Strategies Among First Year Nursing Students in the College of Polytech Mara, Kota Bharu, Kelantan [master's thesis]. Kota Bharu: Universiti Sains Malaysia; 2007.

33. Lai N, Nalliah S, Jutti RC, Hla Y, Lim VK. The educational environment and self-perceived clinical competence of senior medical students in a Malaysian medical school. Educ Health (Abingdon). 2009;22(2):148

34. Al-Ayed IH, Sheik SA. Assessment of the educational environment at the College of Medicine of King Saud University, Riyadh. East Mediterr Health J. 2008;14(4):953-959.

35. Audin K, Davy J, Barkham M. University quality of life and learning (UNIQoLL): An approach to student well-being, satisfaction and institutional change. Journal of Further and Higher Education. 2003;27(4):365-382.

36. Varma R, Tiyagi E, Gupta JK. Determining the quality of educational climate across multiple undergraduate teaching sites using the DREEM inventory. BMC Med Educ. 2005;5(1):8.

37. Zamzuri AT, Ali AN, Roff S, McAleer S. Students perceptions of the educational environment at dental training college. Malaysian Dent J. 2004;25:15-26.

38. Miles S, Leinster SJ. Comparing staff and student perceptions of the student experience at a new medical school. Med Teach. 2009;31(6):539-546.

39. Fidelma D, McAleer S, Roff S. Assessment of the undergraduate medical education environment in a large UK medical school. Health Educ J. 2006;65(2):149-158.

40. Edgren G, Haffling AC, Jakobsson U, McAleer S, Danielsen N. Comparing the educational environment (as measured by DREEM) at two different stages of curriculum reform. Med Teach. 2010;32(6): e233-e238

41. Philbin M, Meier E, Huffman S, Boverie P. A survey of gender and learning styles. Sex Roles. A Journal of Research. 1995;32(7-8): 485-494.

42. A1-Sketty AJS. Student Nurses' Perceptions of the Climate of Their Learning Environment in Three Institutes of Nursing in the Sultanate of Oman [masters dissertation]. Dundee: University of Dundee; 2003.

43. Al-Qahtani MFM. Approaches to Study and Learning Environment in Medical Schools with Special Reference to the Gulf Countries [PhD thesis]. Dundee: University of Dundee; 1999.
Advances in Medical Education and Practice

\section{Publish your work in this journal}

Advances in Medical Education and Practice is an international, peerreviewed, open access journal that aims to present and publish research on Medical Education covering medical, dental, nursing and allied health care professional education. The journal covers undergraduate education, postgraduate training and continuing medical education
Dovepress

including emerging trends and innovative models linking education, research, and health care services. The manuscript management system is completely online and includes a very quick and fair peer-review system. Visit http://www.dovepress.com/testimonials.php to read real quotes from published authors. 